\title{
BIVALVE HARVESTING AND PRODUCTION IN PORTUGAL: AN OVERVIEW
}

\author{
JACINTA OLIVEIRA, ${ }^{1,2 *}$ FERNANDA CASTILHO, ${ }^{2}$ ÂNGELA CUNHA ${ }^{1}$ \\ AND MÁRIO JORGE PEREIRA ${ }^{1}$ \\ ${ }^{1}$ Departamento de Biologia e CESAM, Universidade de Aveiro, Campus Universitário de Santiago, 3810- \\ 193 Aveiro, Portugal; ${ }^{2}$ Instituto Nacional de Recursos Biológicos, I. P./IPIMAR Matosinhos, Avenida \\ General Norton de Matos, no. 84, 4450-208 Matosinhos, Portugal
}

\begin{abstract}
The exploitation of bivalves is an ancient activity in Portugal, with social, economic and cultural importance. The exploitation of shellfish is largely dependent on the capture and production of molluscs. Bivalves have a relevant impact on both the harvesting and production sectors. In the production sector, bivalves are suitably represented, but the higher incomes are obtained mostly from captures. Clams and cockles are the main harvested bivalves, whereas clams and oysters were the most produced. Produced or captured bivalves (live, fresh, frozen, or canned) are targeted mainly to the national market whereas Japanese oysters are entirely exported and mussels are channeled for both markets. Exploitation of bivalves has shown important progress; however, there is still considerable potential for expansion of this sector in Portugal. New strategies to overcome constraints in this activity are urgently needed —namely, (1) improving communication among stakeholders, (2) encouraging the organization of the sector, and (3) adding value to the product by creating new market opportunities.
\end{abstract}

KEY WORDS: shellfisheries, bivalve production, shellfish economy, shellfish quality, Portugal

\section{INTRODUCTION}

Bivalve molluscs represent a significant proportion of the world's fishery sector. The harvesting and commercialization of bivalves occurs from the north to the south of Portugal, with significant impact on the national economy. A great contribution comes from the Tagus estuary, which harbors the largest natural oyster bed in Europe (Silva \& Batista 2008).

The exploitation of bivalve molluscs results from two different activities: harvesting and production. The capture of wild animals can occur either in open-sea coastal waters or in inshore banks and natural ponds (lagoons and estuaries) (Paquotte \& Lem 2008). This capture procedure is designated harvesting. Production requires capture of seeds by means of larvae collectors and their transference to nurseries; shellfish farming can then occur either in inshore or offshore (Silva \& Batista 2008).

The exploitation of bivalve molluscs is an ancient activity; therefore, the accumulated expertise and the tradition of artisanal cultivation make the techniques for raising bivalves simple and readily adaptable to most of the Portuguese coast (Rice 1992). Recent advances in the cultivation technology contributed to a significant increase in production (Helm \& Bourne 2004). Moreover, because bivalve molluscs are filter feeders, depending on the natural primary production at the cultivation site, feeding costs are not implicated (Rice 1992, Helm \& Bourne 2004). Also, they generally require minimum husbandry (Helm \& Bourne 2004) and exhibit a wide range of temperature tolerance $\left(5^{\circ}-35^{\circ} \mathrm{C}\right)$. Furthermore, the somatic growth rate increases 2- or 3-fold for a temperature increase of $10^{\circ} \mathrm{C}$ (Rice 1992). These features combined make the exploitation of bivalve molluscs highly attractive.

Harvesting and production activities are aimed at obtaining safe and high-quality products for human consumption. Safety usually refers to the level of risk associated with illness or death caused by ingestion of a seafood product that is contaminated (Cato 1998, Oliveira et al. 2011). Quality is most often

*Corresponding author. E-mail: jacinta.bio@gmail.com DOI: $10.2983 / 035.032 .0334$ associated with appearance, flavor, and texture, but it also includes nutritional value, shelf life, level of additives, presence of shell imperfections, size and uniformity, and presence of food preservatives (Cato 1998).

The improvement of the systems involved in the production and harvesting of shellfish across different levels of this sector (government agencies, producer/fisher, traders, and consumers) could lead to a more profitable and sustainable development. Here, we describe the evolving scenario of the activities associated with the capture and production of bivalves in Portugal, suggesting further measures for future development.

\section{BIVALVE IN PORTUGUESE FOOD CULTURE MOLLUSCS}

Portugal has one of the world's highest per-capita consumption of seafood products (about $58.50 \mathrm{~kg} /$ person/y) (Paquotte \& Lem 2008). The integration of bivalves in the food culture of the Portuguese is related mainly to tradition, product availability, dietary and nutritional reasons, changing lifestyles, economics, and population growth (Cato 1998, Fauconneau 2002; Murchie et al. 2005).

In some countries, religion also influences the food culture. For instance, dietary laws of Seventh-Day Adventists, Jews, Muslims (Hanafi), and the Shi'ites (Ja'fari) forbid the consumption of shellfish. However, in Portugal, $84.50 \%$ of the Portuguese population is Roman Catholic and the remaining $9.00 \%$ of the population declare themselves to be nonreligious (INE 2001). This means that the predominant religion has no dietary restrictions with respect to shellfish.

Bivalve molluscs play an increasing role in the Portuguese food culture (Fonseca et al. 2006). Their tenderness and easy digestibility, in combination with being additive free and minimally processed, make fresh shellfish highly appreciated by Portuguese consumers as well as by tourists (Fonseca et al. 2006). Usually eaten raw or slightly cooked, with little or no garnishing, some of the most appreciated Portuguese dishes usually combine fish, shellfish, and meat, such as arroz de marisco (seafood rice), caldeirada, amêijoas à bulhão pato, cataplana, and carne de porco à alentejana (Rosa-Limpo et al. 1946). 
Besides its value as a traditional culinary dish, bivalves are nutritionally important and their benefits to health have been widely recognized (Bandarra et al. 2004, Orban et al. 2007). The nutritional value of bivalve molluscs is primarily dependent on the quality of the aquatic environment from which they originate, which ensures both a healthy and safe product for consumption (Bandarra et al. 2004, Orban et al. 2007). Water temperature, nutrient availability, and the reproductive cycle of animals may also influence the biochemical composition and meat quality of some bivalves (Karakoltsidis et al. 1995, Orban et al. 2002). Although the nutritional value varies among bivalve species, protein content is considered similar to that of milk and eggs. In most Portuguese bivalve species, the protein content is approximately $13.0 \%$ (15.0\% in common cockles and $17.0 \%$ in scallops) (Bandarra et al. 2004, Silva \& Batista 2008, Oliveira et al. 2011). Molluscan shellfish almost fulfill the balanced demand for essential amino acids in adult consumers (Fauconneau 2002). Carbohydrate content is largely composed of glycogen and varies throughout the year according to the reproductive cycle of bivalves. Fat content is low (usually, not exceeding $3.0 \%$ ), suitable for a healthy diet, with the amount of unsaturated fatty acids (particularly cholesterol-reducing omega-3 fatty acids) being greater than the amount of saturated fatty acids. Last, Portuguese seafood has a high content of vitamins A, D, E, and B12, and minerals (Cato 1998, Bandarra et al. 2004, Silva \& Batista 2008). The health benefits that arise from eating shellfish are related to their nutritional composition. Seafood consumption can help prevent or reduce the ingestion of excessive calories, cholesterol, and total and saturated fats (Cato 1998).

\section{AREAS FOR HARVESTING AND PRODUCTION OF BIVALVES}

Portugal is located in southern Europe, with an area of $92090 \mathrm{~km}^{2}$. It is the westernmost country of continental Europe and occupies the Atlantic front of the Iberian Peninsula, being bordered by the Atlantic Ocean to its west and Spain to the north (Dill 1993). Because of its geographical position, Portugal combines some characteristics favorable to the exploitation of bivalves: (1) an extended exclusive economic zone with more than $3,877,408 \mathrm{~km}^{2}$ (Executive summary PT-ES: Continental shell submission of Portugal. Pursuant to Article 76, paragraph 8, of the United States Convention on the law of the sea. 2009. Estrutura de Missão para a Extensão da Plataforma Continental/Task Group for the Extension of the Continental Shelf. Lisbon: Ministry of Defense.); (2) 1,793 km of coast under the influence of different currents; (3) Mediterranean climate with a temperate climate with rainy winters and hot and dry summers in the south, and a temperate climate with rainy winters and few hot and dry summers in the north, according to the climatic classification of Köppen-Geiger (Bebianno 1995); (4) average water temperatures ranging from $13-18^{\circ} \mathrm{C}$, according to latitude (higher values are expected in the south, whereas lower ones are expected along the north coast); (5) the existence of estuaries and lagoons along the coast; and (6) a high primary production (Dill 1993. Machás et al. 2003).

The quality of the shellfish harvesting and production areas depends on the geographical characteristics of the coast and coexistence with other human activities (agriculture, urban, industry, and livestock, among others) that generate pollution and strongly influence water quality (Laing \& Spencer 1997,
Silva \& Batista 2008). These organisms filter large volumes of water to obtain oxygen and nutrients; therefore, bioaccumulation of chemical and biological contaminants is unavoidable (Oliveira et al. 2011). This problem has been promoting an ongoing effort by several official entities to ensure the quality and safety of shellfish prior to consumption (Silva \& Batista 2008). The classification of harvesting and production areas, according to their risk in relation to food safety, allows anticipating the corresponding microbiological quality of shellfish caught in those areas. Accordingly, production area classifications determine the type of treatment required for the shellfish to be submitted prior to marketing, thereby helping to reduce risks to public health (Silva \& Batista 2008). All shellfish intended for human consumption must meet the specific microbiological criteria set out in annex I of regulation no. 2073/2005 (Commission Regulation (EC) No 2073/2005 of November 15, 2005 on microbiological criteria for foodstuffs. Official Journal of the European Union.) and regulation no. 1441/2007 (Commission Regulation (EC) No 1441/2007 of December 5, 2007 amending Regulation (EC) No 2073/2005 on microbiological criteria for foodstuffs. Official Journal of the European Union.) Chapter V, section VII, annex III of regulation no. 853/2004 (Corrigendum to Regulation (EC) No $853 / 2004$ of the European Parliament and of the Council of April 29, 2004 laying down specific hygiene rules for food of animal origin. Official Journal of the European Union L 139 of April 30, 2004.); annex II, chapter II of regulation no. 854/ 2004 (Corrigendum to Regulation (EC) No 854/2004 of the European Parliament and of the Council of 29 April 2004 laying down specific rules for the organization of official controls on products of animal origin intended for human consumption. Official Journal of the European Union L 139 of April 30, 2004.) and regulation no. 1021/2008 (Commission Regulation (EC) No 1021/2008 of October 17, 2008 amending Annexes I, II and III to Regulation (EC) No 854/2004 of the European Parliament and of the Council laying down specific rules for the organization of official controls on products of animal origin intended for human consumption and Regulation (EC) No 2076/2005 as regards live bivalve molluscs, certain fishery products and staff assisting with official controls in slaughterhouses. Official Journal of the European Union.) define the quality parameters of shellfish prior to consumption. The maximum levels of toxic metals in bivalves are specified in regulation nos. 1881/2006 (Commission Regulation (EC) No 1881/2006 of December 19, 2006 setting maximum levels for certain contaminants in foodstuffs. Official Journal of the European Union.) and 629/2008 (Commission Regulation (EC) No 629/2008 of July 2, 2008 amending Regulation (EC) No 1881/2006 setting maximum levels for certain contaminants in foodstuffs. Official Journal of the European Union.)

The state laboratory of the National Institute of the Biological Resources/Fisheries and Sea Research Institute - INRB, I. P./IPIMAR (currently designated as the Portuguese Institute of Sea and Atmosphere, I.P. - IPMA, I.P.) of the Ministry of Agriculture, Rural Development and Fisheries, is the authority responsible for (1) the sanitary control of bivalves for human consumption, (2) technical and scientific advice regarding installation of new bottom culture beds, and (3) the monitoring and classification of the harvesting and production areas according to the health standards for the production and marketing of live bivalve molluscs for direct human consumption (decree-law nos. 
112/95, 236/98, and 1421/2006) (Campos \& Cachola 2006). According to order no. 14515/2010 of the president of INRB, I. P. as of July 17, 2010 (republic diary no. 182, series II), the harvesting and production areas are distributed in 17 estuarine zones and 9 coastal areas (Fig. 1) (Silva \& Batista 2008). The areas that register the highest exploitation of bivalves are the center of Portugal and Algarve (southern Portugal), together accounting for $72.70 \%$ of the total national exploitation. These regions, display the most suitable physical conditions for harvest and production of bivalves (DGPA/INE 2011), which is usually carried out by fishers or by nonprofessional fishers, directly involving 8,000-10,000 people in the Algarve only (Campos \& Cachola 2006).

\section{EVOLUTIONARY SCENARIO OF SHELLFISH HARVESTING DURING THE PAST DECADE}

During the past $12 \mathrm{y}$, fish dominated captures in both brackish and marine waters, accounting for $88.05 \%$ of the total amount, representing $73.07 \%$ of the economic profit. Shellfish harvesting accounted for $11.92 \%$ in quantity $(26.89 \%$ in economic value) and the remaining captures $(0.03 \%)$ were of other aquatic animals (DGRM/INE 2012).

Molluscan shellfish represents a significant portion of the total shellfish harvesting, largely exceeding (by about 11 times) the capture of crustaceans (Fig. 2A). Indeed, bivalves, squid, octopi, and snails accounted for $10.93 \%$ of total shellfish captures (20.36\% of the economic profit). The remaining $0.99 \%$ was the result of the capture of crustaceans (crabs, shrimps, lobsters, and crawfish). Despite this difference in the amount of catches, the economic profit does not show the same trend. The overall economic value associated with molluscs only exceeds 3 -fold the economic value of crustaceans (Fig. 2B). This is mainly a result of the availability of these food products in the natural environment and the selling price on the markets.

Global analysis of the captured quantities of molluscs (Fig. 2A) demonstrates an erratic fluctuation over time. The quantity of captured molluscs ranged from 14,193 t (in 2001)$20,341 \mathrm{t}$ in 2008 , whereas profits varied between $€ 38,023,000$ (in 1999) and $€ 74,215,000$ (in 2008). Despite these variations, the period from 1999 to 2003 registered a growth of $33.15 \%$ in mollusc captures, with a corresponding growth in economic value. The overall mean growth rate for mollusc captures was $1.67 \% / y$ and $5.73 \%$ for the economic value.

Captures of crustaceans grew at a rate of $2.45 \% / \mathrm{y}$ whereas the economic profit revealed a decrease of $0.58 \%$. The highest value of crustacean captures was observed in 1999, when 2,426 t was obtained, representing an economic profit of $€ 23,848,000$.

From 1999 to 2005, the economic profit related to crustacean captures decreased $49.77 \%$, reaching the lowest value $(€ 10,317,000)$ within the analyzed decade, thus reflecting the reduction in captures. During the past $6 \mathrm{y}$, capture of crustaceans increased, but there was not a proportional increase in the economic value, leading to an overall negative economic growth. The economic crisis has affected the consumption of all food products in Portugal, shellfish included. This may explain the declines in economic value from 2010 to 2011 .

During the past $12 \mathrm{y}$, the slow growth observed in shellfish harvesting reflects the application and efficiency of European and national control policies. These policies empower control measures related to the need to preserve stocks of natural

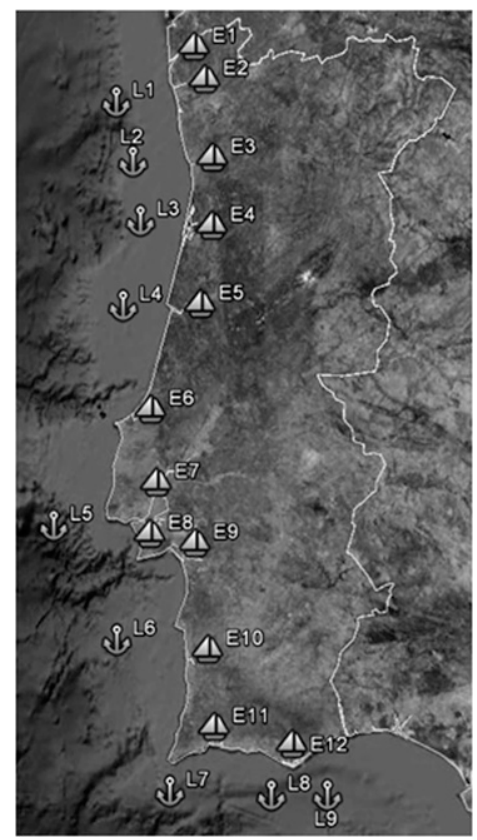

Figure 1. Exploitation zones of bivalves in Portugal. Coastal zones (L) are highlighted by an anchor and estuarine zones (E) are indicated by a boat. L1, Viana; L2, Matosinhos; L3, Aveiro; L4, Nazaré and Figueira da Foz; L5, Lisboa and Peniche; L6, Sines and Setúbal; L7, Portimão and Lagos; L8, Olhão and Faro; L9, Vila Real de Santo António and Tavira; E1, Estuário do Lima; E2, Estuário do Minho; E3, Estuário do Douro; E4, Ria de Aveiro; E5, Estuário do Mondego; E6, Lagoa de Óbidos; E7, Estuário do Tejo; E8, Lagoa de Albufeira; E9, Estuário do Sado; E10, Estuário de Mira; E11, Rio do Alvor and Rio Arade (2 zones); and E12, Ria Formosa (5 zones). (Satellite image from GoogleMaps, accessed January 12, 2013).

resources, which ultimately lead to periods of forbidden capture of different species to improve sustainability.

\section{Captured Bivalves}

Several species of bivalves are commercialized in Portugal (Ministry of Agriculture, Rural Development and Fisheries. Decree no. 587/2006 of June 22, 2006. Republic Diary, series I B, no. 119.), (Presidency of the Council of Ministers. Rectification no. 52/2006. Republic Diary, series I, no. 159.), Garibaldi \& Busilacchi 2010), but the most harvested bivalves consist of cockles, clams, razor shells, mussels, and oysters (Table 1, Fig. 3 ). During the past decade, capture of different species of bivalves fluctuated erratically, contributing $21.19 \%$ to total mollusc captures. Despite fluctuations, cockles and clams remain the 2 most captured bivalves, followed by razor shells, mussels, and, last, oysters (Fig. 3). In 2011, cockles represented 51.48\% of the national capture of bivalve molluscs, accounting for $€ 1,271,000$; clams represented $39.73 \%$, corresponding to a profit of $€ 3,534,000$. Mussels, razor shells, and oysters contributed to a lower proportion, with only $4.20 \%$ $(€ 64,000), 2.55 \%(€ 186,000)$, and $2.04 \%$ (€68,000), respectively (DGPA/INE 2011).

\section{Evolution of Commercial Transactions Registered with Captured Shellfish}

International commercial transactions of molluscs and crustaceans were analyzed, considering two main groups depending 

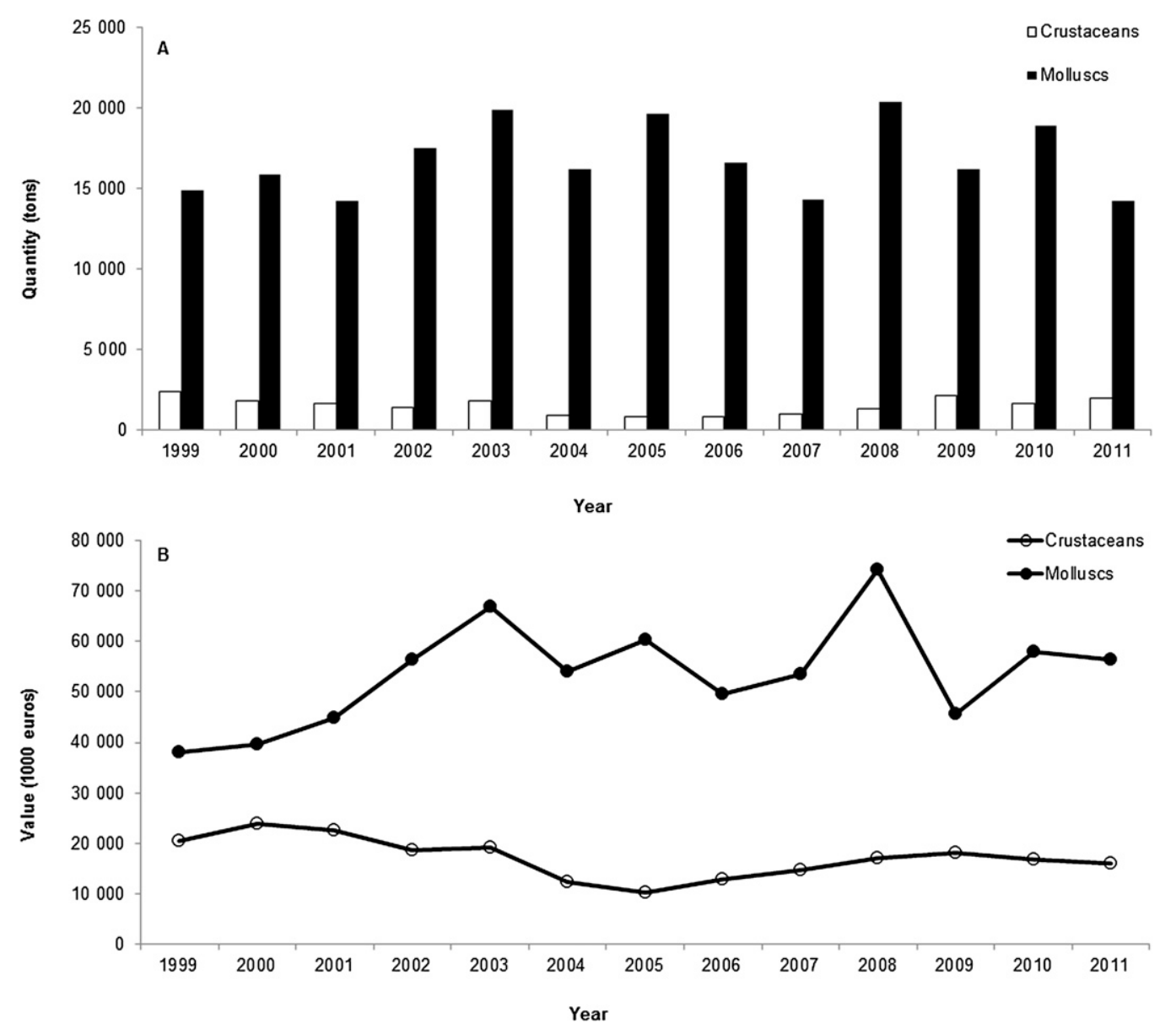

Figure 2. (A, B) Evolution of the quantity (A) and economic value (B) of the captured shellfish from 1999 to 2011 (DGPA/INE 2000, DGPA/INE 2001, DGPA/INE 2002, DGPA/INE 2003, DGPA/INE 2004, DGPA/INE 2005, DGPA/INE 2006, DGPA/INE 2007, DGPA/INE 2008, DGPA/INE 2009, DGPA/INE 2010, DGPA/INE 2011, DGRM/INE 2012).

on the shellfish preservation condition: (1) live, fresh, chilled or frozen, or (2) canned.

\section{Live, Fresh, Chilled or Frozen Shellfish}

During the past $12 \mathrm{y}$, Portuguese imports of live, fresh, chilled, or frozen shellfish largely exceed the exported products. Also, transactions related to molluscs far exceeded those for crustaceans.

Spain, France, Netherlands, Switzerland, India, Mexico, and China are the main suppliers of shellfish that is imported (DGRM/INE 2012). Imports have grown at a rate of approximately $4.61 \% / y$ for molluscs and $4.78 \% / y$ for crustaceans (Fig. 4A). The period from 2004 to 2009 registered the most significant growth in imports, reaching $63,118 \mathrm{t}$ of molluscs $(€ 159,373,000)$ and $17,370 \mathrm{t}$ of crustaceans $(€ 55,615,000)$. The economic value associated with molluscs has shown a progressive growth $(10.19 \% / y)$, whereas the increase $(3.17 \%)$ was less pronounced in the case of crustaceans (Fig. 4B). Nevertheless, the costs associated with the import of molluscs only exceed those related to crustaceans in the past $2 \mathrm{y}$. This resulted from a reduction in the number of imported molluscs (10.27\%) and crustaceans (18.43\%) during the same period (Fig. 4).

The main target markets for exportation of the shellfish harvested or produced in Portugal are Spain, Italy, France, the
United States, Switzerland, Angola, Thailand, and Vietnam (DGRM/INE 2012). During the past $12 \mathrm{y}$, the quantity of exported molluscs exceeded the quantity of crustaceans, but this did not correlate with the resulting profit. For instance, in 1999 to 2001 and in 2008, the economic profit resulting from the sale of crustaceans exceeded those of molluscs. From 2002 to 2008, the profits resulting from shellfish exports remained almost the same, at approximately $€ 75,184,000 / y$, with equal contributions from molluscs and crustaceans (Fig. 4). After a gradual growth observed between 2007 and 2009, the exportation of molluscs strongly increased during the past $2 \mathrm{y}$, resulting in $€ 152,252,000$ of economic value $(67.10 \%$ of total shellfish output) (DGPA/ INE 2011). In 2011, a total of 32,421 t of shellfish was sold to other countries, representing a profit of $€ 226,910,000$ (Fig. 4). Despite the higher exportation during the past few years, the balance of the international trade of shellfish was still negative, with a loss of $€ 140,868,000$ (DGRM/INE 2012).

\section{Canned Shellfish}

Throughout the period analyzed, the collection of statistical data only considered canned shellfish as a whole; hence, no distinction was made between molluscs or crustaceans. The commercialization of canned shellfish was not significant when compared with the trade of live, fresh, chilled, or frozen shellfish. 
TABLE 1.

Species of bivalve molluses according to their commercial interest in Portugal (data from 2009).

\begin{tabular}{|c|c|c|c|c|}
\hline Scientific name & Author citation & English name & 3-Alpha* & ISSCAAP \\
\hline Cerastoderma edule & (Linnaeus, 1758) & $\begin{array}{l}\text { Common edible } \\
\text { cockle }\end{array}$ & $\mathrm{COC}$ & 56 \\
\hline Cerastoderma glaucum & (Bruguiere, 1789) & $\begin{array}{l}\text { Olive green } \\
\text { cockle }\end{array}$ & KTG & 56 \\
\hline Crassostrea angulata & (Lamark, 1819) & Portuguese oyster & OYP & 53 \\
\hline Crassostrea gigas & (Thunberg, 1793) & $\begin{array}{l}\text { Pacific cupped } \\
\text { oyster, Japanese } \\
\text { oyster }\end{array}$ & OYG & 53 \\
\hline Ensis ensis & (Linnaeus, 1758) & $\begin{array}{l}\text { Pod razor } \\
\text { shell }\end{array}$ & EQE & 56 \\
\hline Ensis siliqua & (Linnaeus, 1758) & $\begin{array}{l}\text { Sword razor } \\
\text { shell }\end{array}$ & EQI & 56 \\
\hline Mytilus edulis & (Linnaeus, 1758) & Blue mussel & MUS & 54 \\
\hline Mytilus galloprovincialis & (Lamarck, 1819) & Mediterranean mussel & MSM & 54 \\
\hline Ostrea edulis & (Linnaeus, 1758) & $\begin{array}{l}\text { European flat } \\
\text { oyster }\end{array}$ & OYF & 53 \\
\hline Pharus legumen & (Linnaeus, 1758) & Bean solen & FRL & 56 \\
\hline Ruditapes decussatus & (Linnaeus, 1758) & $\begin{array}{l}\text { Grooved carpet } \\
\text { shell }\end{array}$ & CTG & 56 \\
\hline Ruditapes philippinarum & (Adams \& Reeve, 1850) & $\begin{array}{l}\text { Japanese carpet } \\
\text { shell }\end{array}$ & CLJ & 56 \\
\hline Solen marginatus & (Pulteney, 1799) & $\begin{array}{l}\text { European razor } \\
\text { clam }\end{array}$ & RAE & 56 \\
\hline Spisula solida & (Linnaeus, 1758) & $\begin{array}{l}\text { Solid surf } \\
\text { clam }\end{array}$ & ULO & 56 \\
\hline Venerupis pullastra & (Montagu, 1803) & $\begin{array}{l}\text { Pullet carpet } \\
\text { shell }\end{array}$ & CTS & 56 \\
\hline
\end{tabular}

* A unique code made of 3 letters that is widely used for the exchange of data with national correspondents and among fishery agencies. $\dagger$ Code assigned according to the FAO International Standard Statistical Classification for Aquatic Animals and Plants, which divides commercial species on the basis of their taxonomic, ecological, and economic characteristics into the group of molluscs, in the division of clams, cockles, and ark shells (56), mussels (54), and oysters (53). (Adapted from Ministry of Agriculture, Rural Development and Fisheries. Decree no. 587/2006 of June 22, 2006. Republic Diary, series I B, no. 119, and Presidency of the Council of Ministers. Rectification no. 52/2006. Republic Diary, series I, no. 159. and Garibaldi and Busilacchi (2010)).

For instance, in 2011, imports of live, fresh, chilled, or frozen shellfish was about 21 times greater than imports of canned shellfish, and export of live, fresh, chilled, or frozen shellfish were about 11 times greater than exports of canned shellfish (Fig. 5). It is noteworthy that, in 2011, the highest values of canned shellfish transactions were registered with imports, reaching 4,042 t $(€ 17,526,000)$ and exports totaling 2,954 tons (€12,145,000; Fig. 6). Within the past $12 \mathrm{y}$, imports of canned shellfish have always exceeded exports. From 1999 to 2006, profits associated with exports remained almost constant whereas imports grew

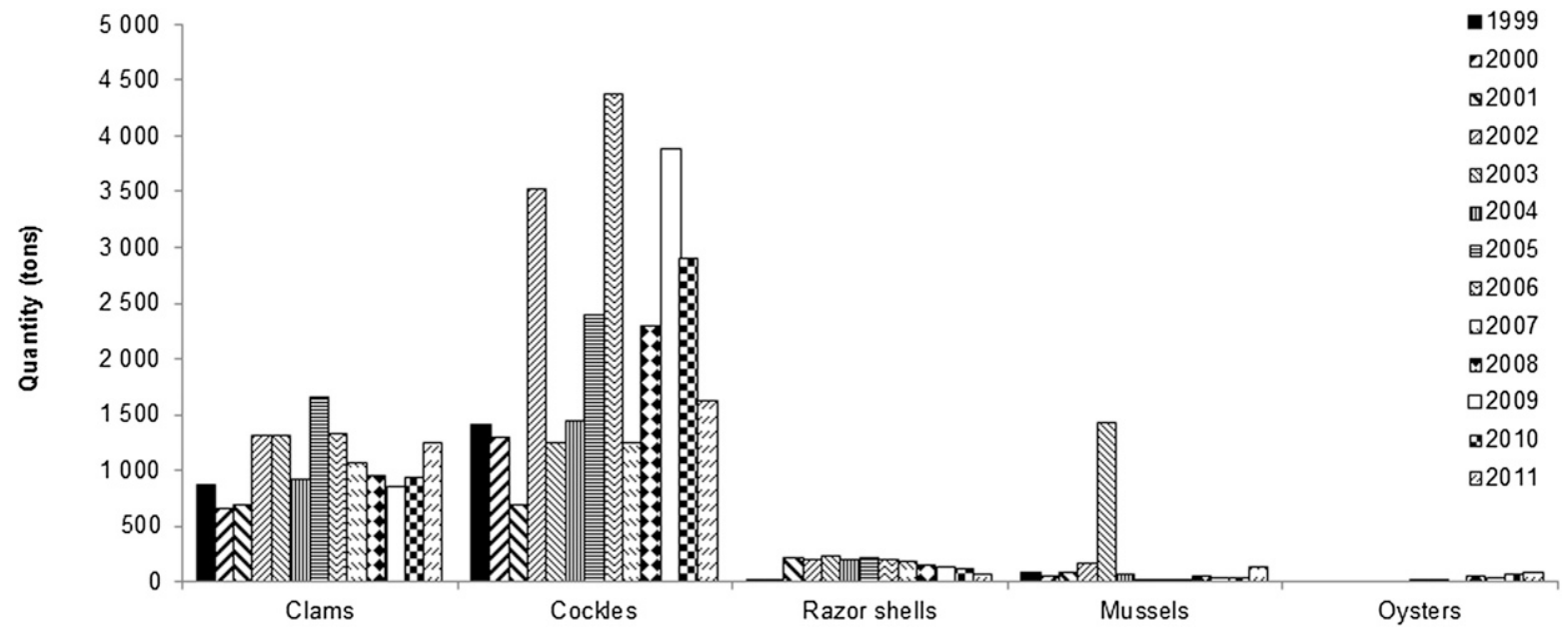

Figure 3. Evolution of the values related to harvesting of bivalve molluses from 1999 to 2011 (DGPA/INE 2000, DGPA/INE 2001, DGPA/INE 2002, DGPA/INE 2003, DGPA/INE 2004, DGPA/INE 2005, DGPA/INE 2006, DGPA/INE 2007, DGPA/INE 2008, DGPA/INE 2009, DGPA/INE 2010, DGPA/INE 2011, DGRM/INE 2012). 

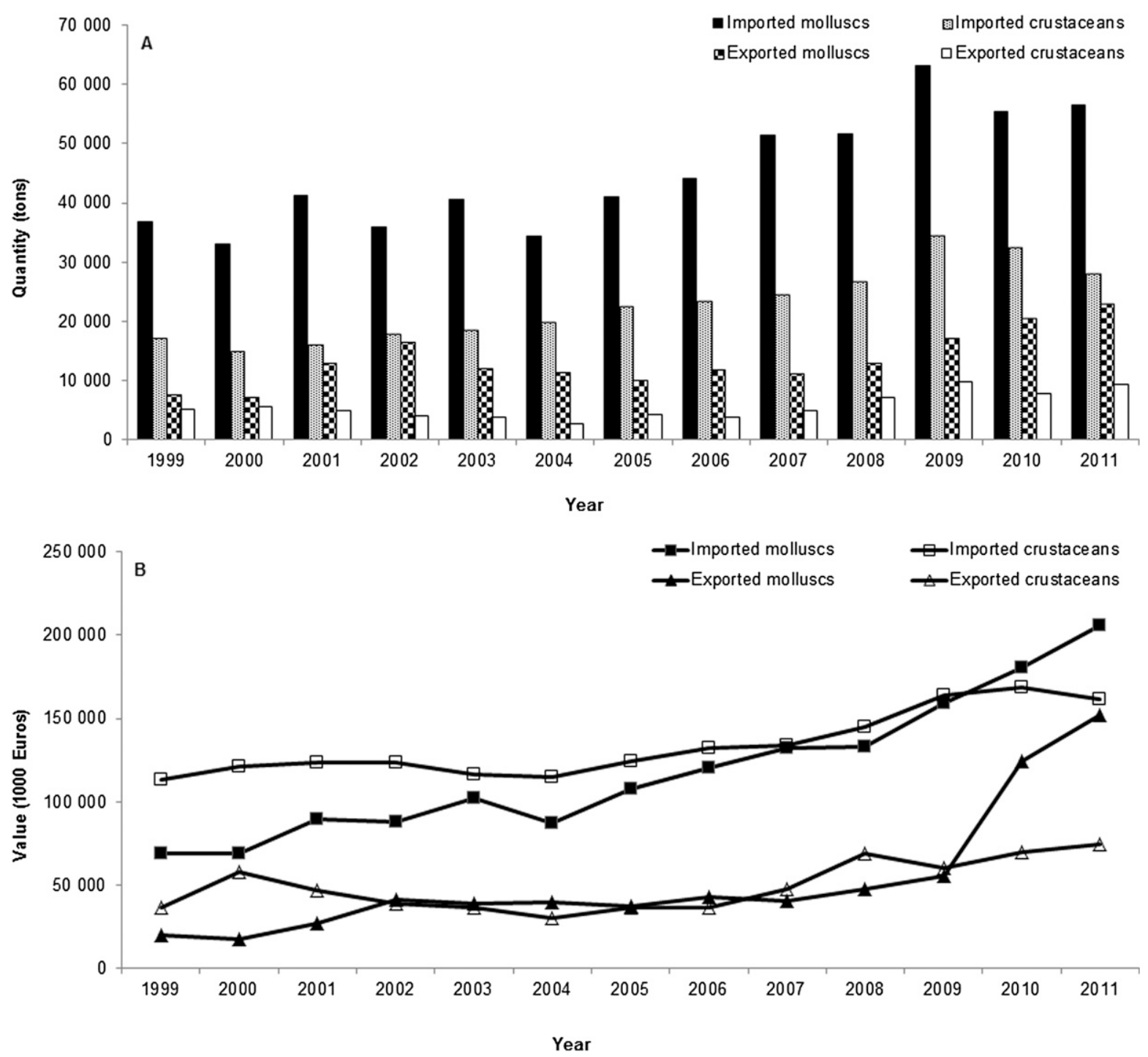

Figure 4. (A, B) Evolution of the quantity (A) and economic value (B) related to the imports and exports of live, fresh, chilled, or frozen shellfish from 1999 to 2011. Quantity values of 2008 were extrapolated from quantity values of 2009, because only the economic value was available (DGPA/INE 2000, DGPA/INE 2001, DGPA/INE 2002, DGPA/INE 2003, DGPA/INE 2004, DGPA/INE 2005, DGPA/INE 2006, DGPA/INE 2007, DGPA/INE 2008, DGPA/INE 2009, DGPA/INE 2010, DGPA/INE 2011, DGRM/INE 2012).

slowly. During the past $6 \mathrm{y}$, significant progress has been observed in both imports and exports of canned shellfish, but exports recorded a higher mean rate of growth per year $(58.13 \%)$ than imports $(9.35 \%$; Fig. 6). This recent expansion of the canning industry may contribute to minimize the existing negative export/ import balance in international shellfish transactions. Indeed, there is an expected trend of canned shellfish commercialization to increase as a result of convenience of use (Silva \& Batista 2008).

\section{EVOLUTIONARY SCENARIO OF SHELLFISH PRODUCTION DURING THE PAST DECADE}

From 1999 to 2010, Portuguese shellfish production grew $30.39 \%$, with an average annual growth rate of $4.40 \%$ (Fig. 7 ). This increase in the production reflects infrastructural improvements, wider use of equipment, greater availability of juveniles, the introduction of more production systems, and the increase in the number of aquaculture units (Bernardino 2000).
The production of crustaceans, mainly Ditch shrimp (Palaemonetes varians), is unrepresentative compared with the production of molluscs. Mollusc production includes two main groups: bivalves and cuttlefish (the latter with an extremely reduced share of $>1 \mathrm{t} / \mathrm{y}$, on average). As a consequence, mollusc production depends primarily on bivalve production. Looking at the past decade, it can be seen that production had a tendency to fluctuate strongly over time. A significant decrease in mollusc production (i.e., in bivalve production) was observed and may be related to (1) the number of sites available (which may not be a limiting factor per se, although all sites must have or obtain a classification) (Laing \& Spencer 1997); (2) progressive deterioration of the water quality (Bernardino 2000); (3) reduction of natural bivalve beds as a consequence of high catch rates (Pillay \& Kutty 2005); (4) relative abundance of many of the main commercial species along the Portuguese coast (European Commission. 2010. Fish/2006/09. MRAG consortium: socioeconomic dependency case study reports. Assessment of 


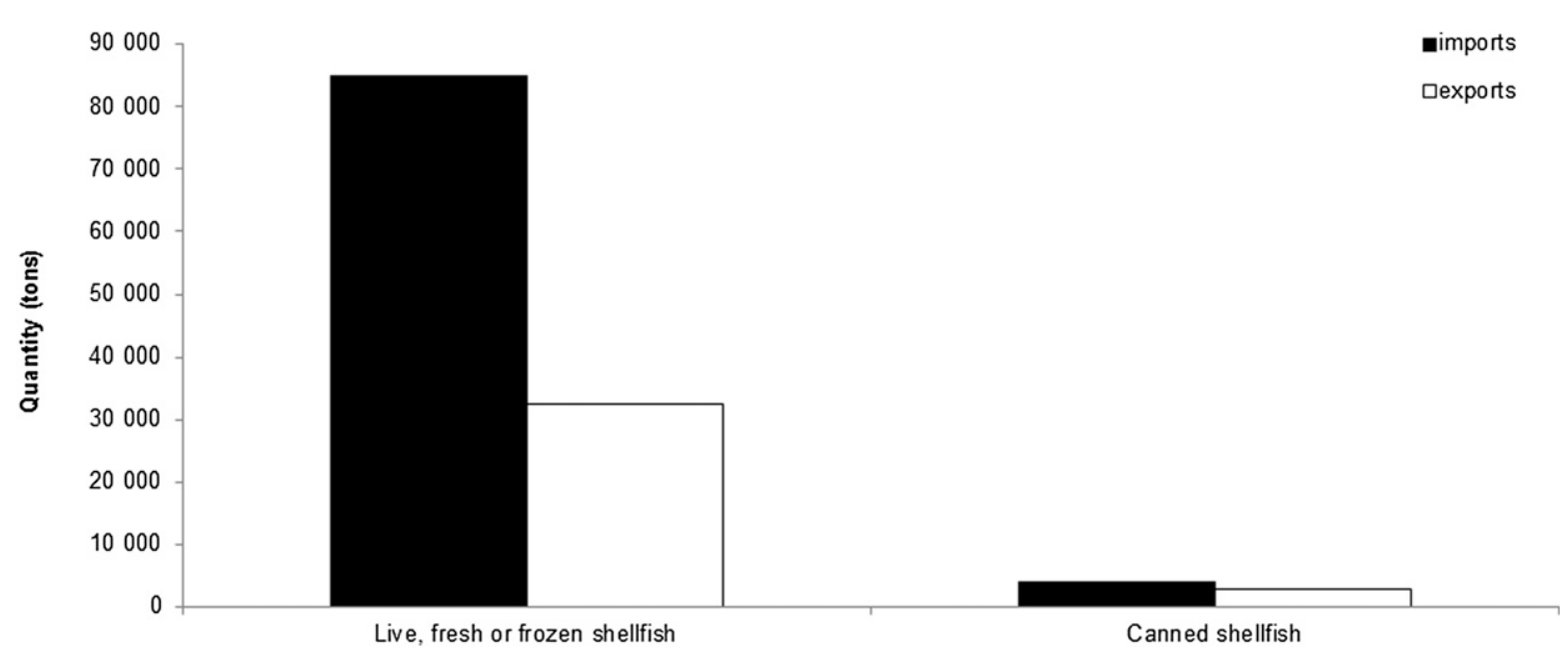

Figure 5. Transactions of live, fresh, or frozen shellfish and of canned shellfish in 2011 (DGRM/INE 2012).

the status, development and diversification of fisheriesdependent communities. Aveiro, Portugal. Marine Resources \& Fisheries Consultants. 34 pp.); (5) a shrinking fleet with poorly trained professionals (European Commission. 2010. Fish/2006/09. MRAG consortium: socioeconomic dependency case study reports. Assessment of the status, development and diversification of fisheries-dependent communities. Aveiro, Portugal. Marine Resources \& Fisheries Consultants. 34 pp.); (6) mortality associated with bivalve handling (Laing \& Spencer 1997); (7) inadequate relaying of bivalve seeds (Bernardino 2000); and (8) mortality caused by predators (Laing \& Spencer 1997). The highest variation observed was in 2003 and 2004. Comparing the volume registered in 2004 with the previous year, there was a reduction of $31.27 \%$, mainly a result in the breakdown from the high mortality of the grooved carpet shell (Ruditapes decussates) in production units in Algarve (DGPA/INE 2006).

\section{Produced Bivalves}

Production of bivalves occurs almost exclusively under the extensive regime, and the market size is dependent on a regular annual supply of juveniles, known as seed or spat, for growing. These juveniles may be obtained locally on natural beds or acquired from national or international facilities (Laing \& Spencer 1997). Nurseries for the production of bivalves are mostly located in the Ria Formosa (E12 in Fig. 1) (DGPA/INE 2011). The offshore production of bivalves (defined as $12 \mathrm{mi}$ from the coastline) includes 20 facilities located only in Algarve (158.40 ha) and the Peninsula de Setúbal (0.36 ha), which occupy a total area of 158.76 ha. This reduced number and distribution is easily explained by the existence of less suitable environmental conditions along the coast (hydrodynamics) in the north of Portugal, where production of bivalves occurs mainly inshore.

During the past few years, clams have contributed the most to bivalve production (representing $93.89 \%$ of total bivalve production); followed by oysters, with only $5.52 \%$; then mussels $(0.30 \%)$, cockles $(0.30 \%)$, and razor shells $(0.01 \%$; Fig. 8).

\section{Evolution of the Transactions Registered with Produced Shellfish}

Data on production transactions are only available for 2005 through 2010. These data show that the majority of the produced shellfish was targeted at the national market and the remaining was exported. The difference between these 2 markets was about 9-fold higher in favor of the former, and most of the profit $(98.05 \%)$ resulted from transactions that occurred in the national market (Fig. 9). There was a mean growth rate of $9.04 \%$ in the import of produced shellfish to the national market. On the other hand, the export of shellfish products to international markets has shown erratic development (Fig. 9A). Clams and cockles were commercialized exclusively in the national market, whereas the production of the Japanese oyster was aimed entirely at the international market (Fig. 10). In 2010, clams were the most sold mollusc $(2,539 \mathrm{t})$, representing a total profit of $€ 23,943,000$ (DGPA/INE 2011). In the same year, $160 \mathrm{t}$ of Japanese oysters were commercialized in the international market, accounting for $€ 336,000$ (DGPA/INE 2011). Production of mussels was channeled for both the national and international markets (Fig. 10). Most of the bivalve production was exported to western European countries, particularly France and Spain (Campos \& Cachola 2006). In Portugal, bivalves were sold in local markets and were mainly consumed fresh by the resident population and tourists in restaurants and seafood festivals. For instance, the Algarve tourism industry is now promoting gastronomic tourism as an important complement to the sustainability of the bivalve production sector (Campos \& Cachola 2006).

\section{STATE OF THE EXPLOITATION OF BIVALVE MOLLUSCS}

The values analyzed in this section were supplied by fishers. Because they tend to undervalue the quantities harvested or cultured, as well as their profits (Bernardino 2000, Silva \& Batista 2008), the global estimate associated with shellfish production and trade might be underestimated. Nevertheless, some important trends were noted.

Captures represented the foremost supply for shellfish market compared with the production sector. Molluscs have contributed the most for both the production and the capture 

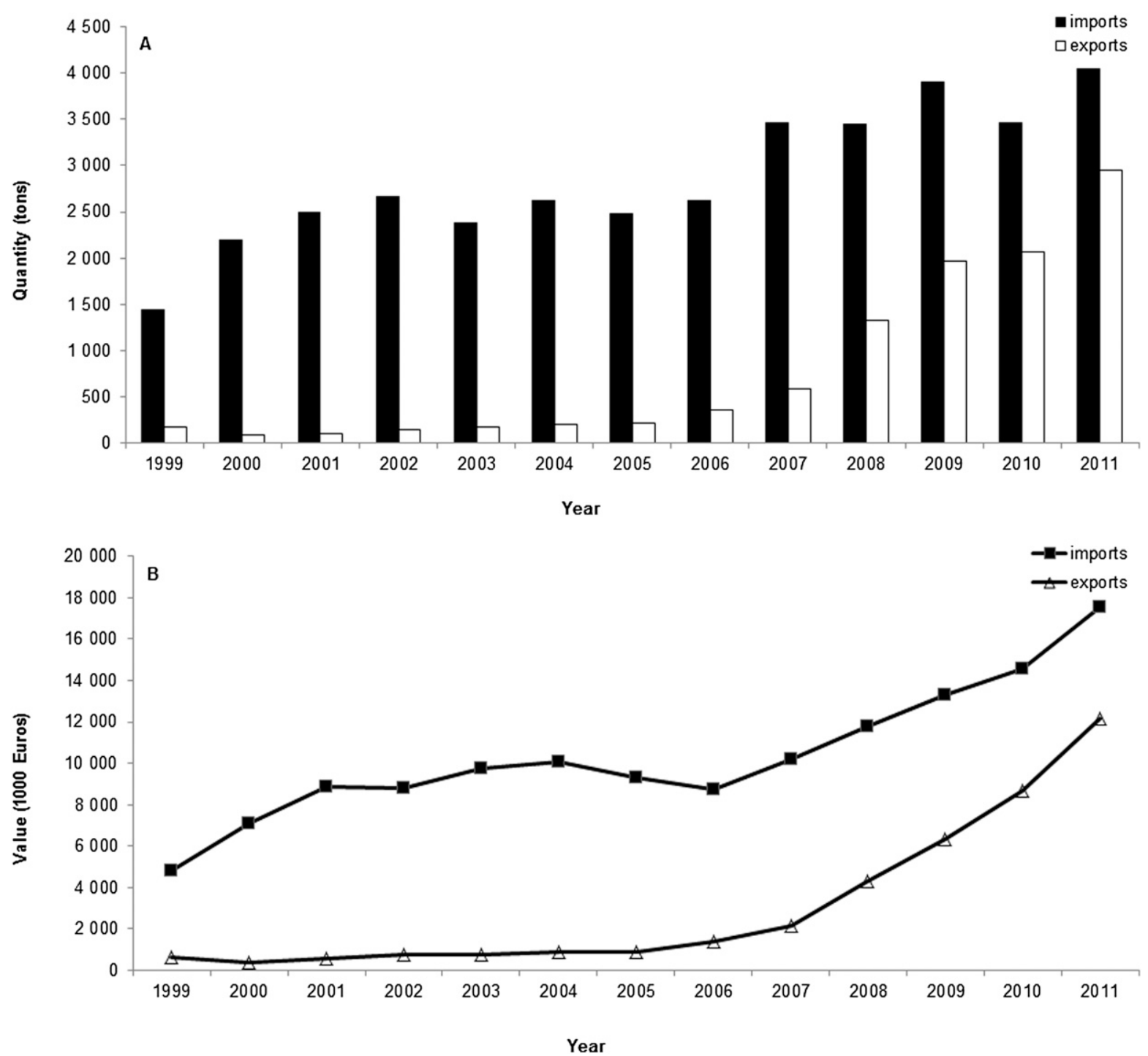

Figure 6. (A, B) Evolution of the quantity (A) and economic value (B) related to the imports and exports of canned shellfish from 1999 to 2011 . Quantity values of 2008 were extrapolated from quantity values of 2009, because only the economic value was available (DGPA/INE 2000, DGPA/INE 2001, DGPA/INE 2002, DGPA/INE 2003, DGPA/INE 2004, DGPA/INE 2005, DGPA/INE 2006, DGPA/INE 2007, DGPA/INE 2008, DGPA/INE 2009, DGPA/INE 2010, DGPA/INE 2011, DGRM/INE 2012).

sectors. Within this group, bivalves reasonably contributed to this result. Although production of bivalves was fairly significant in the production sector, the higher incomes were mostly obtained from captures. In 2010, 4,043 t of bivalves were captured, representing $€ 5,569,000$, whereas production totaled $3,336 \mathrm{t}$ of bivalves and $€ 19,941,000$.

Cockles and clams were the most captured bivalves, whereas production was dominated by clams, oysters, and mussels. In general, analysis of the transactions during the past decade show that, typically, imports largely exceeded exports. Because the shellfish was either captured and sold alive, fresh, frozen, or canned, or produced, there was a global negative balance in the shellfish sector. Shellfish consumption and the demands of consumers may explain the large amount of imports. Nevertheless, these values, along with other costs related to shellfish exploitation, show that this sector, particularly that of the bivalves, has the potential to evolve. Therefore, new and prompt strategies to invert this trend are of paramount importance.

\section{EXPLOITATION OF BIVALVE MOLLUSCS: BARRIERS AND STRATEGIES}

The exploitation of marine resources has been a mainstay for coastal communities. Initially, it was a balanced and sustainable activity, practiced mainly at a subsistence level and as a supplementary source of income. However, it has currently reached a dramatic overexploitation as a consequence of the sharp increase in demands associated with population growth. The increase of pressure on marine resources is a result of (1) the increasing need for coastal areas for leisure and tourism and the consequent increase in the exploitation effort, (2) the rapid development of capture technologies, (3) the adjustment of the laws regulating the sector, and (4) the progressive reorganization of the fishing sector. Improvements in this sector may counterbalance this trend and contribute to a more sustainable development. Indeed, the European Fisheries Fund (EFF) was founded to support the fisheries sector, ensuring the sustainable 

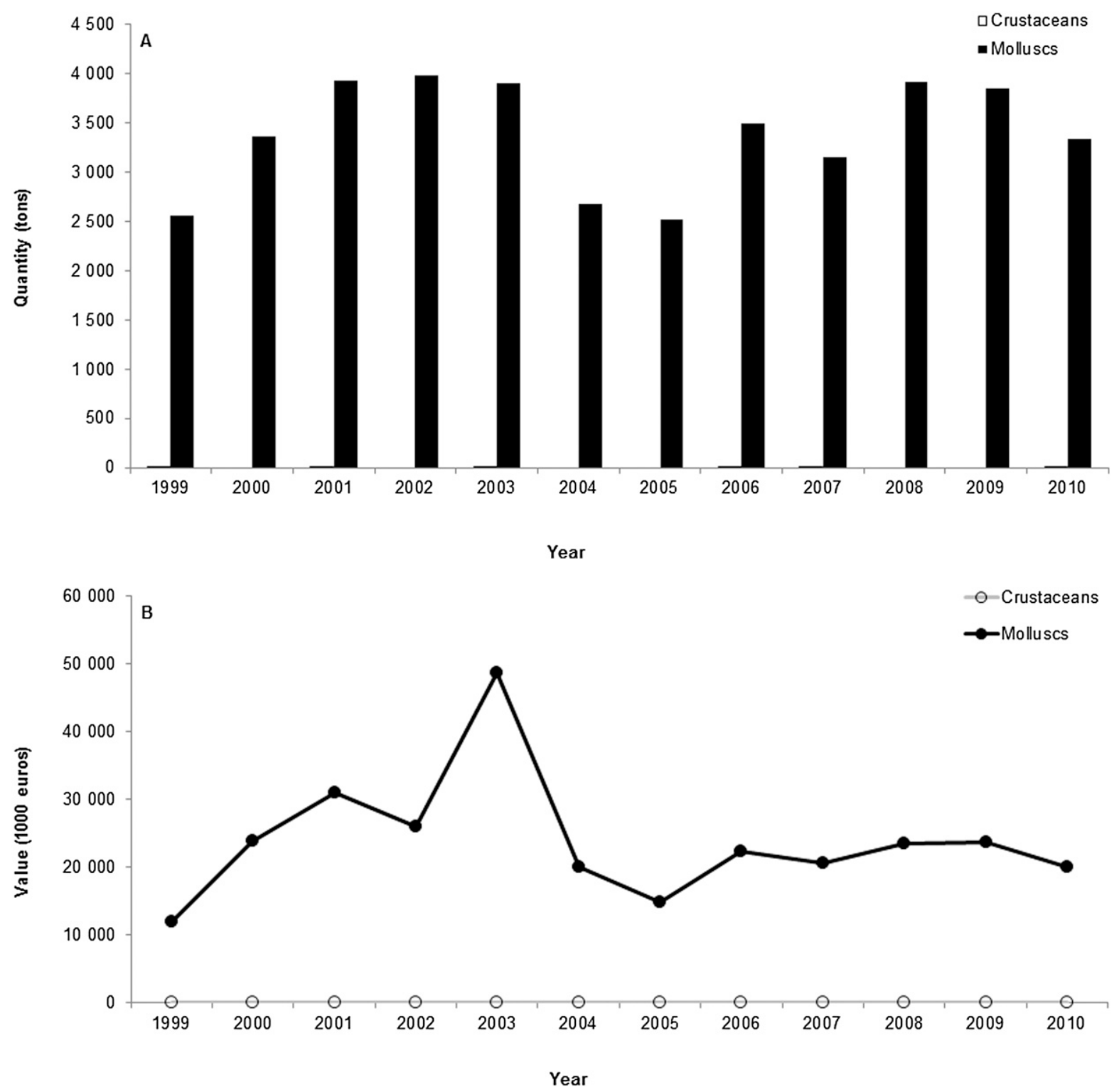

Figure 7. (A, B) Evolution of the quantity (A) and economic value (B) of the produced shellfish from 1999 to 2010 (DGPA/INE 2000, DGPA/INE 2001, DGPA/INE 2002, DGPA/INE 2003, DGPA/INE 2004, DGPA/INE 2005, DGPA/INE 2006, DGPA/INE 2007, DGPA/INE 2008, DGPA/INE 2009, DGPA/INE 2010, DGPA/INE 2011).

exploitation of living aquatic resources and providing conditions for sustainability at the economic, environmental, and social levels. To accomplish the guiding principles set out in EFF, the Portuguese fisheries program PROMAR was developed. In 2011, Portugal had an execution rate of $41.00 \%$ of the principles established in PROMAR 2007 to 2013, and the executed investment was $45.00 \%$ of the total forecasted investment. The main lines of action were the execution of projects based on the adaptation of fishery efforts, in the investment in aquaculture, transformation, and commercialization of products of fishery and aquaculture; and on the sustainable development of fishing zones.

Despite the Portuguese fisheries operational program, several barriers limit, to a greater or lesser extent, the possibilities of developing harvesting and production of shellfish: the training of fishers and fish farmers, transfer of technology to the interested parties in the sector, organization of the sector, competitiveness of prices, monitoring of the products and of the productive process, sanitary certification of breeding areas and mollusc products, acquisition or assignment of suitable coastal areas and their legal allocation to production, and establishment of marketing strategies.

\section{Transference of Knowledge and Technology in the Sector}

Artisanal capture is thought to play an important socioeconomic role in the subsistence of fishing communities. For instance, bivalves continue to be freely caught by people along the margins of lagoons and coastal areas. The number of fulltime professionals interested in joining the fishery activity is declining because financial rewards have been decreasing year after year. In addition, there are less people available to work on 


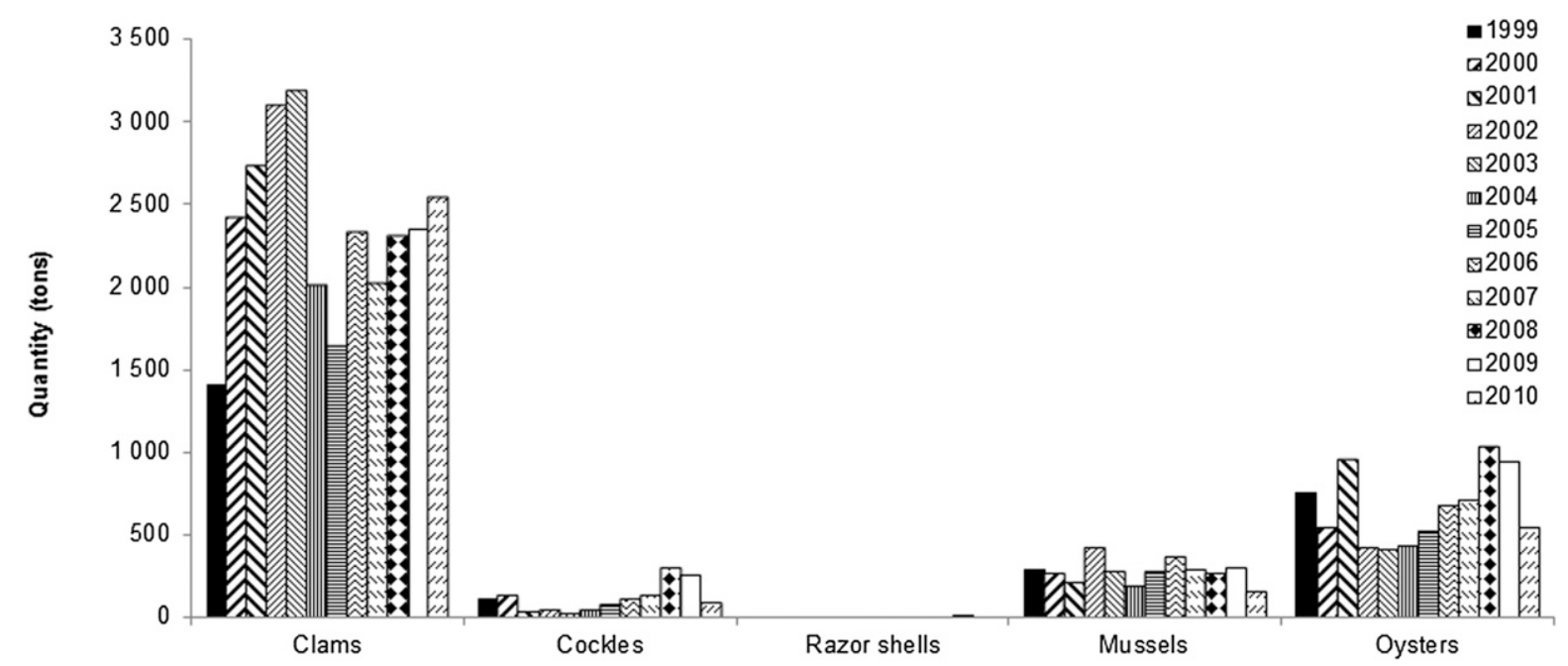

Figure 8. Evolution of the values related to production of bivalve molluscs from 1999 to 2010 (DGPA/INE 2000, DGPA/INE 2001, DGPA/INE 2002, DGPA/INE 2003, DGPA/INE 2004, DGPA/INE 2005, DGPA/INE 2006, DGPA/INE 2007, DGPA/INE 2008, DGPA/INE 2009, DGPA/INE 2010, DGPA/INE 2011).

fishing boats. Fisheries are seen by the younger generations as an unattractive economic activity, which involves a great amount of hard work for often a very small financial compensation. Considering this scenario, only people with low qualifications join the fishing crews, often after exhausting the possibilities of finding any other type of job. This represents a real constraint on the development of fisheries, because these people are often unreliable, not motivated, and rapidly leave if another job opportunity arises, even if it means an even lower income (European Commission. 2010. Fish/2006/09. MRAG consortium: socioeconomic dependency case study reports. Assessment of the status, development and diversification of fisheries-dependent communities. Aveiro, Portugal. Marine Resources \& Fisheries Consultants. 34 pp.). The latest data showed that 647 full-time professionals $(4.00 \%)$ had no qualifications, 13,827 $(86.20 \%)$ went to elementary school, 1,236 $(7.70 \%)$ had middle-level education, $25(0.20 \%)$ went to high school, and only $313(2.00 \%)$ were graduates (DGPA/INE 2011). In 2011, there were 217 training sessions, involving 3,457 trainees, with a success rate of $84.00 \%$. The existence of these training sessions provided either by governmental or private entities is crucial for the development of this sector, and contributes to the requalification and training of farmers and producers to obtain information on how to increase production/ capture and add value to the product, optimizing production, depuration, legislation, marketing, and community organization, among other aspects.

The success of the sector involves the knowledge of the social, economic, and cultural contexts of the target public. It also involves knowledge of marketing processes and, during its implementation, knowledge of the biological, zootechnical, and environmental characteristics, along with food safety rules and legislation. This requires governmental supervision inherent in products intended for human food. From this point of view, the involvement of multidisciplinary teams with qualified professionals trained to deal with a diversity of tasks, is urgently needed. Both universities and government institutes have been conducting work directed toward aquaculture practices. Often, scientific research is directed to the ecosystem and natural resources, and lacks commercial perspective. It is therefore essential that research target the real needs of this sector, acting as a promotion factor. This requires the definition of research priorities, which should cover (1) the implementation of chemical and microbiological monitoring for classification and certification of both products and production areas because, in their current form, the process is obsolete and unrepresentative (Oliveira et al. 2011); (2) the assessment of shelf life for precooked, cooled, and frozen bivalves; (3) modernization and improvement of the efficiency of the depuration process; (4) the study of alternatives for shellfish processing; and (5) evaluation of other bivalve species with the potential to be used in aquaculture to achieve a higher diversification of commercialized products, thus enhancing competition with other countries. The dissemination and transfer of knowledge/technology among researchers, management agents, and fishers would be a relevant factor in the production of shellfish. It is important to recognize that the process of technology implementation is slow, because it requires a range of knowledge and skills from researchers, which often go beyond standard technical procedures. Thus, the integration of technical assistants (previously selected and trained) to support research in the institutes would facilitate the cross-communication of information and contribute to achieve fast and improved results.

\section{Organization of the Sector}

Fishers have difficulty in being recognized as professionals of a promising commercial sector. Because of the intrinsic characteristics of this activity and of the fishing communities, it is challenging to bring people together under organized entities that could centralize critical steps in the production chain. Associations and cooperatives are common structures in the economy of other countries, such as Spain, that were created with the purpose of overcoming the derogatory professional status, the dispersion of efforts and resources, and the weakening of the productive sector. 

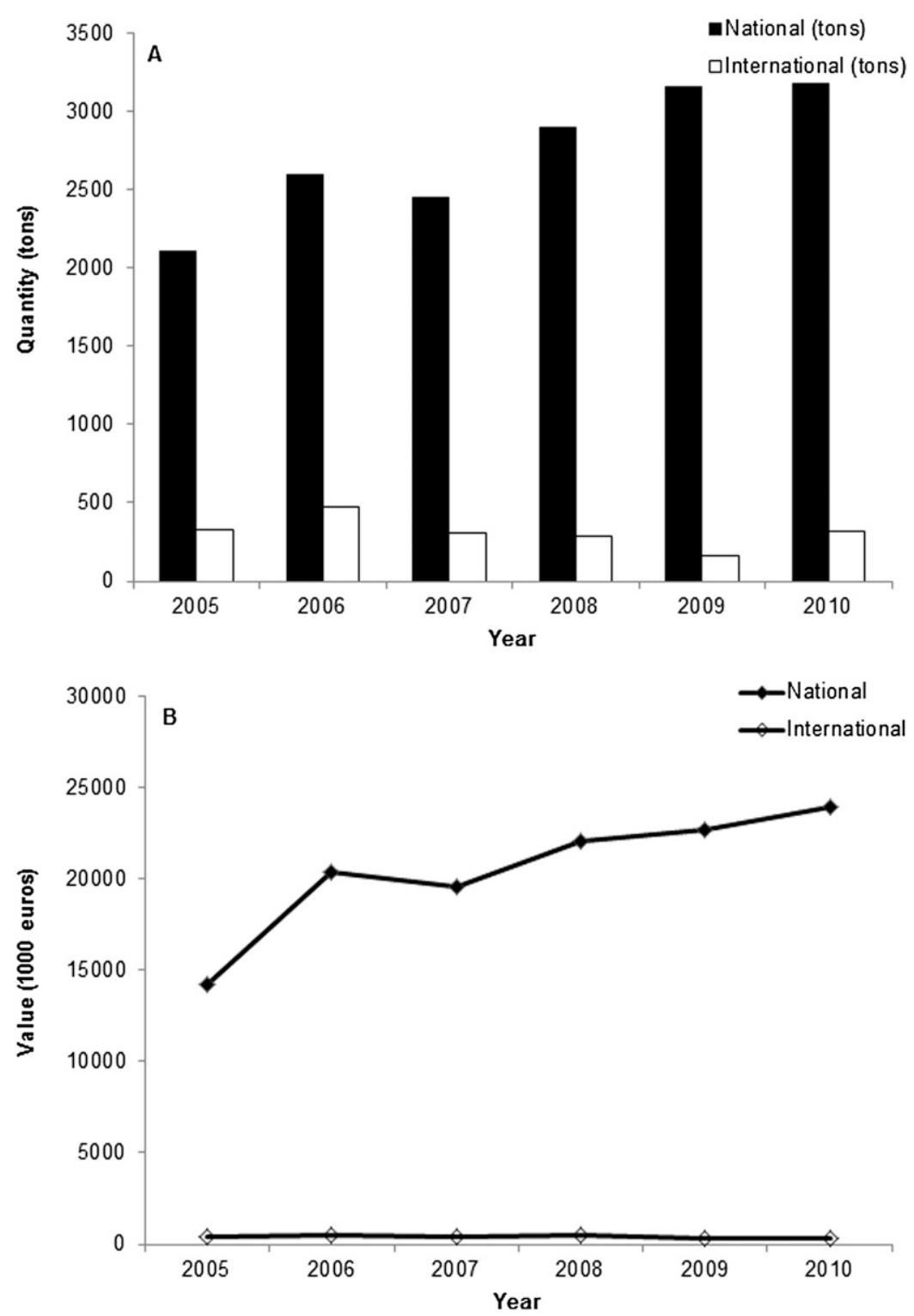

Figure 9. (A, B) Evolution of the quantity (A) and economic value (B) of the national and international transactions of bivalve molluses from 2005 to 2010 (DGPA/INE 2006, DGPA/INE 2007, DGPA/INE 2008, DGPA/INE 2009, DGPA/INE 2010, DGPA/INE 2011).

In 2010, there were 43 Portuguese organizations of fishers and fish farmers, covering a total of 5,564 professionals (DGPA/INE 2011). Technical support for the creation of associations or cooperatives, as well as lectures, seminars, and workshops promoted by institutions working directly in the field would help to encourage the creation of these consortia. However, some difficulties are still frequent even when fishers are organized in associations or networks. The source of these issues may be related to financial and administrative bureaucracy, insurance coverage, management of conflicts with other activities such as tourism and fishing, and the implementation of incentives for the development of the activity. The performance of these organizations has had positive effects in terms of competitiveness and productivity of the sector, social security for employees, property insurance, and providing a guarantee of the quality of the product. However, restructure of these organizations is desirable to allow effective intervention in other areas, particularly in the marketing of the product and in providing access to wider and more competitive markets.

\section{Sanitary State of Harvesting and Production Areas}

The increase in population density, industrialization, need for better treatment of sewage disposal, and small-river outlets or diffuse land runoff are some of the ways by which bivalves become exposed to pollution, retarding growth and diminishing sanitary quality (Oliveira et al. 2011). The classification of the production areas of bivalve molluscs according to the sanitary standards in A, B and C has contributed to the possibility of knowing the origin of the product and their level of contamination, leading to a faster evaluation of the treatment required prior to commercialization (Oliveira et al. 2011). A joint effort must be effected to reduce negative environmental impacts and 


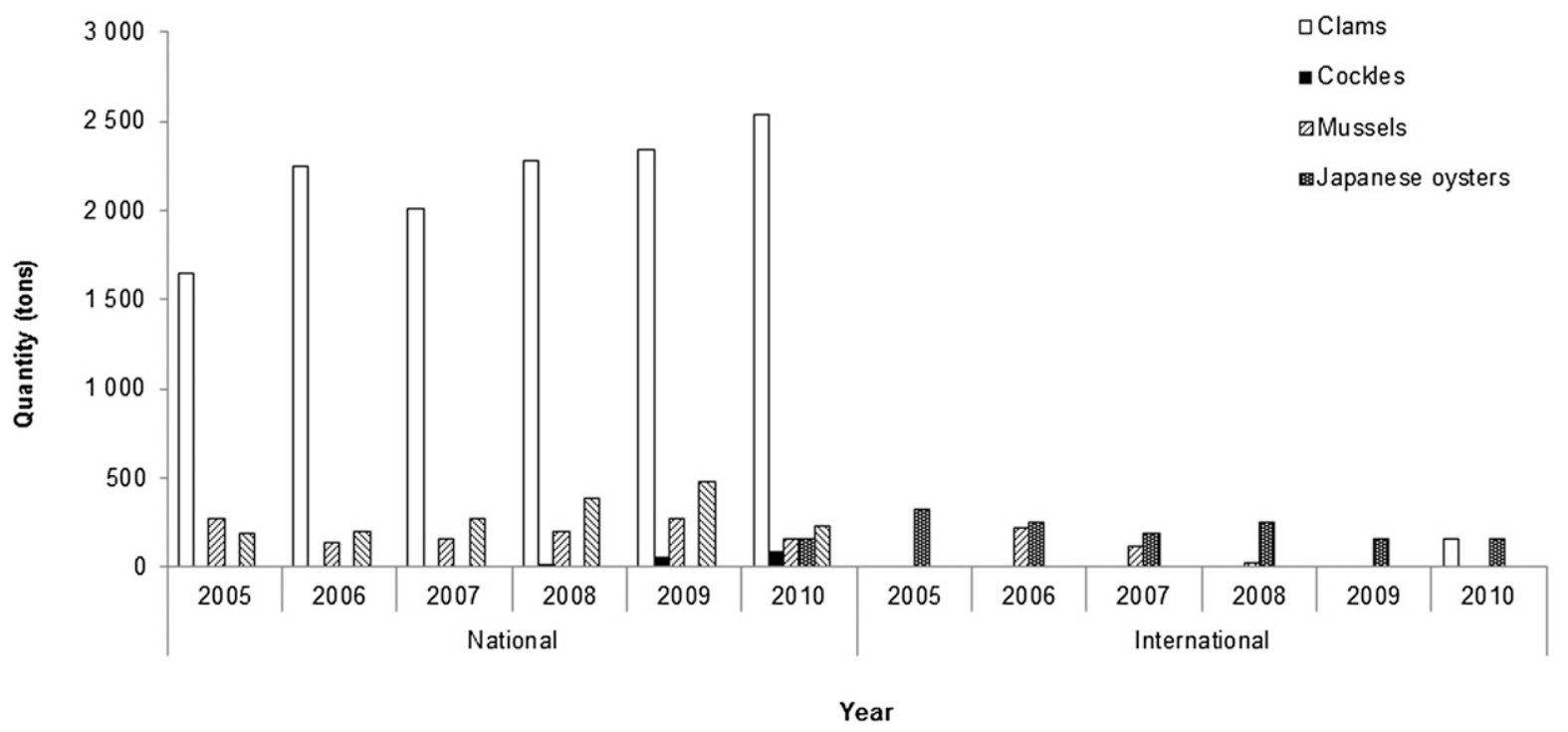

Figure 10. Evolution of the values related to the national and international transactions of bivalve molluses from 2005 to 2010 (DGPA/INE 2006, DGPA/INE 2007, DGPA/INE 2008, DGPA/INE 2009, DGPA/INE 2010, DGPA/INE 2011).

improve harvesting and production areas. Restrictions on bivalve harvesting are often applied when the area does not meet required sanitary standards. In addition, increased strictness of legislation has led to a decrease in the availability of approved harvesting areas. Also, the current unfavorable economic conjecture demands the reduction of costs. Accordingly, the sampling sites used to assess the sanitary state of the production areas might be reduced, resulting in misjudgment of the real sanitary state of the production areas and thus decreasing the number of areas acceptable for shellfish harvesting and production. Microbial analyses are essential to confirm the sanitary status of an area, but the assessment of the evolution of the sanitary status both in space and time might give a more comprehensive overview of the harvesting and production areas, contributing to a more efficient management of this activity. Predictive models are essential because they can help to prevent economic losses associated with the deterioration of shellfish beds. Therefore, the accessibility, acquisition, and legalization of bivalve exploitation areas, under an extensive regime, should be better documented, creating conditions for the organized expansion of the sector along the coast. This should take into consideration the protection of natural resources and the development of complementary economic activities.

Fish farmers invested significantly and have uncontrollable losses caused by environmental contamination, human influence in wild areas, environmental factors (such as predation and red tide), and ecological disasters. Loss of productivity is also associated with the period of closure that occurs from May 1 to June 15, which began in January 1998 (regulatory order no. 11/80 of May 7, paragraph 1, article 15; decree-law no. 261/89 of August 17). The closed season occurs in all zones and subzones of the coastal ocean for some species of bivalve molluscs (ruling no. 1228/10 of December 6). Although there might be a monetary compensation from the government during this period, it always involves financial losses for producers. The existence of studies defining the period of closure for each species is essential to minimize economic losses.
Adding Value to the Fishery and Fish Farming Products

Certification is a way of ensuring that the product complies with the requirements of high organoleptic quality. This would add value to the product and to mollusc marketing, providing a good return on the initial investment. Sanitary certification of a product from aquaculture raises the price over the different levels of the market chain, because of its justified quality and safety for the consumer. The quality of certified products enhances consumer confidence, which is indispensable for the socioeconomic viability of this activity. Nevertheless, certification is often given after depuration of the bivalves. It is well established that depuration procedures need to be improved (Oliveira et al. 2011), and this process usually results in a loss of weight and quality of the product. The use of bacteriophages during depuration, as a method to achieve healthier bivalves more rapidly would mitigate these losses, with the advantage of excluding important pathogens as well as autochthonous bacteria (Oliveira et al. 2011). Bacteriophage administration during depuration would reduce the depuration time (before getting the product to the market), consequently maximizing the commercial circuit. This methodology is already being used in other food products and has been proposed to be implemented in the bivalve mollusc sector (Oliveira et al. 2011). Indeed, Intralytix is the only company in the world with an approved bacteriophage-based preparation as a food additive (FDA 2006). The use of less attractive depurated products for the canning industry not only increases profitability of these products, but also it creates a possibility of expanding this industrial area by creating a new market niche. Also, the development of gourmet products (nationally or regionally) and the attribution of quality labels to seafood products would help to validate this sector of the economy. Given the current economic situation, it is also important to address indirect returns, which include the creation of new employment opportunities and the promotion economic and social stability of coastal populations. 


\section{CONCLUSION}

There is considerable potential for expansion of the bivalve exploitation sector and industry in Portugal, notwithstanding the contribution provided by PROMAR for the development of this sector. Despite the favorable natural conditions of the Portuguese territory, these have not been used to their fullest for effective improvement of bivalve harvesting and production processes, resulting in economic losses. This progress requires joint action of governmental entities, companies, and research centers to effect new strategies, such as the development of certified products and quality labels; marketing strategies that appeal to the benefits of seafood and its subsequent quality; diversification of products, including other bivalve species and different presentations of traditional products; and improvement in the knowledge and characterization (on space and timescales) of favorable areas along the Portuguese coast - without threatening environmental quality - toward a sustainable increase in production. There is a great need to involve and motivate fishers, producers, and the general public, and to improve communication among stakeholders to promote sector sustainability. Investing in innovation and in the quality of the product, making better use of all the fishing opportunities, and taking advantage of the potentials in aquaculture are essential to add value to the fishery and fish farming products (European Commission. 2010. Fish/ 2006/09. MRAG consortium: socioeconomic dependency case study reports. Assessment of the status, development and diversification of fisheries-dependent communities. Aveiro, Portugal. Marine Resources \& Fisheries Consultants. 34 pp.).

\section{ACKNOWLEDGMENTS}

We express our deepest gratitude to Cristina Borges, who responsible for the aquiculture division of the Direção Geral de Recursos Naturais, Segurança e Serviços Marítimos (DGRM); and to Isabel Teixeira, Superior Technician, Direção Geral de Recursos Naturais, Segurança e Serviços Marítimos (DGRM), for providing access to statistical data, without which it would have been difficult to prepare this manuscript. We thank João Mesquita PhD of the Department of Animal Science, Rural Engineering and Veterinary of the Agrarian Superior School; and Felipe Varum PhDs and Alexandra Machado for revising the manuscript. This work was supported by the Portuguese Foundation for Science and Technology in the form of a $\mathrm{PhD}$ grant (SFRH/BD/28747/2006).

\section{LITERATURE CITED}

Bandarra, N. M., M. A. Calhau, L. Oliveira, M. Ramos, M. G. Dias, H. Bartolo, M. R. Faria, M. C. Fonseca, J. Gonçalves, I. Batista \& M. L. Nunes. 2004. Composição e valor nutricional dos produtos da pesca mais consumidos em Portugal. Lisbon: IPIMAR. 103 pp.

Bebianno, M. J. 1995. Effects of pollutants in the Ria Formosa Lagoon, Portugal. Sci. Total Environ. 171:107-115.

Bernardino, F. N. V. 2000. Review of aquaculture development in Portugal. J. Appl. Ichthyol. 16:196-199.

Campos, C. J. A. \& R. A. Cachola. 2006. The introduction of the Japanese carpet shell in coastal lagoon systems of the Algarve (south Portugal): a food safety concern. Internet J. Food Safety 8:1-2.

Cato, J. C. 1998. Economics of hazard analysis and critical control point (HACCP) programmes. FAO fisheries technical paper. Rome: FAO Fisheries Department. 70 pp.

DGPA/INE. 2000. Estatísticas da pesca 1999. Lisbon: Instituto Nacional de Estatística. 78 pp.

DGPA/INE. 2001. Estatísticas da pesca 2000. Lisbon: Instituto Nacional de Estatística. 98 pp.

DGPA/INE. 2002. Estatísticas da pesca 2001. Lisbon: Instituto Nacional de Estatística. 88 pp.

DGPA/INE. 2003. Estatísticas da pesca 2002. Lisbon: Instituto Nacional de Estatística. 78 pp.

DGPA/INE. 2004. Estatísticas da pesca 2003. Lisbon: Instituto Nacional de Estatística. 73 pp.

DGPA/INE. 2005. Estatísticas da pesca 2004. Lisbon: Instituto Nacional de Estatística. 75 pp.

DGPA/INE. 2006. Estatísticas da pesca 2005. Lisbon: Instituto Nacional de Estatística. 79 pp.

DGPA/INE. 2007. Estatísticas da pesca 2006. Lisbon: Instituto Nacional de Estatística. 97 pp.

DGPA/INE. 2008. Estatísticas da pesca 2007. Lisbon: Instituto Nacional de Estatística. 97 pp.

DGPA/INE. 2009. Estatísticas da pesca 2008. Lisbon: Instituto Nacional de Estatística. 98 pp.

DGPA/INE. 2010. Estatísticas da pesca 2009. Lisbon: Instituto Nacional de Estatística. $101 \mathrm{pp}$.

DGPA/INE. 2011. Estatísticas da pesca 2010. Lisbon: Instituto Nacional de Estatística. 101 pp.
DGRM/INE. 2012. Estatísticas da pesca 2011. Lisbon: Instituto Nacional de Estatística. 130 pp.

Dill, W. A. 1993. Inland fisheries of Europe. EIFAC technical paper 52 suppl. Rome: FAO. 296 pp.

FAO. 2010. The state of world fisheries and aquaculture: 2010. Rome: FAO Fisheries and Aquaculture Department. 196 pp.

Fauconneau, B. 2002. Health value and safety quality of aquaculture products. Rev. Med. Vet. 153:331-336.

FDA. 2006. Food Additives Permitted for Direct Addition to Food for Human Consumption; Bacteriophage Preparation. Federal register vol. 71, Issue 160 (August 18, 2006). In: FDA-HHS, editor. Office of the Federal Register, National Archives and Records Administration. pp. 47729-47732.

Fonseca, I. P. D., P. S. Ramos, F. A. Ruano, A. P. Duarte, J. C. Costa, A. C. Almeida, M. L. Falcão \& M. I. Fazendeiro. 2006. Efficacy of commercial cleansing procedures in eliminating Cryptosporidium parvum oocysts from bivalves. J. Eukaryot. Microbiol. 53:S49-S51.

Garibaldi, L. \& S. Busilacchi. 2010. ASFIS List of Species for Fishery Statistics Purposes, Fishery Fact Sheets Collections. FAO statistics and Information Service System 2002. FAO of the United Nations: Fisheries and Aquaculture Department. Available at: http:// www.fao.org/fishery/collection/asfis/en.

Helm, M. M. \& N. Bourne. 2004. Hatchery culture of bivalves: a practical manual. Rome: FAO. 203 pp.

INE. 2001. Censos 2001, resultados definitivos: XIV recenseamento geral da população/IV recenseamento geral da habitação. Lisbon: Instituto Nacional de Estatística. 538 pp.

Karakoltsidis, P. A., A. Zotos \& S. M. Constantinides. 1995. Composition of the commercially important Mediterranean finfish, crustaceans, and molluscs. J. Food Compost. Anal. 8:258-273.

Laing, I. \& B. E. Spencer. 1997. Bivalve cultivation: criteria for selecting a site. Lowestoft: Centre for Environment, Fisheries and Aquaculture Science. 41 pp.

Machás, R., R. Santos \& B. Peterson. 2003. Tracing the flow of organic matter from primary producers to filter feeders in Ria Formosa Lagoon, southern Portugal. Estuaries Coasts 26:846-856.

Murchie, L. W., M. Cruz-Romero, J. P. Kerry, M. Linton, M. F. Patterson, M. Smiddy \& A. L. Kelly. 2005. High pressure processing 
of shellfish: a review of microbiological and other quality aspects. Innov. Food Sci. Emerg. Technol. 6:257-270.

Oliveira, J., A. Cunha, F. Castilho, J. L. Romalde \& M. J. Pereira. 2011. Microbial contamination and purification of bivalve shellfish: crucial aspects in monitoring and future perspectives: a mini-review. Food Contr. 22:805-816.

Orban, E., G. Di Lena, T. Nevigato, I. Casini, R. Caproni, G. Santaroni \& G. Giulini. 2007. Nutritional and commercial quality of the striped Venus clam, Chamelea gallina, from the Adriatic sea. Food Chem. 101:1063-1070

Orban, E., G. Di Lena, T. Nevigato, I. Casini, A. Marzetti \& R. Caproni. 2002. Seasonal changes in meat content, condition index and chemical composition of mussels (Mytilus galloprovincialis) cultured in two different Italian sites. Food Chem. 77:57-65.

Paquotte, P. \& A. Lem. 2008. Seafood markets and trade: a global perspective and an overview of EU Mediterranean countries.
In: B. Basurco, editor. The Mediterranean fisheries sector: a reference publication for the VII Meeting of Ministers of Agriculture and Fisheries of CIHEAM member countries; Options Méditerranéennes, series B: etudes et Recherches (France). Rome: FAO, Fisheries Department, General Fisheries Commission for the Mediterranean. pp. 43-55.

Pillay, T. V. R. \& M. N. Kutty. 2005. Aquaculture: principles and practices. Oxford: Blackwell Publishing. 640 pp.

Rice, M. A. 1992. Bivalve aquaculture in warm tropical and subtropical waters with reference to sanitary water quality, monitoring and post-harvest disinfection. Trop. Sci. 32:179-201.

Rosa-Limpo, B., M. M. Caetano \& J. B. do Canto. 1946. O livro de pantagruel. Lisbon: Temas e Debates. 1191 pp.

Silva, H. A. \& I. Batista. 2008. Produção, salubridade e comercialização de moluscos bivalves em Portugal. Lisbon: IPIMAR. $171 \mathrm{pp}$. 